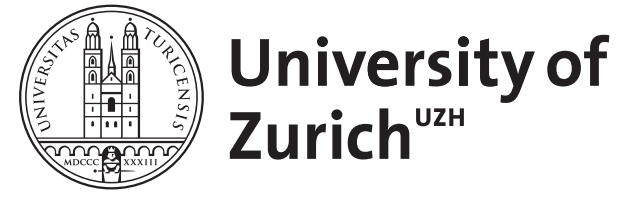
Archive

University of Zurich

University Library

Strickhofstrasse 39

CH-8057 Zurich

www.zora.uzh.ch

Year: 2004

\title{
A note to our authors
}

Roth, Jürgen ; Drenckhahn, Detlev

DOI: https://doi.org/10.1007/s00418-004-0700-2

Posted at the Zurich Open Repository and Archive, University of Zurich

ZORA URL: https://doi.org/10.5167/uzh-156281

Journal Article

Published Version

Originally published at:

Roth, Jürgen; Drenckhahn, Detlev (2004). A note to our authors. Histochemistry and Cell Biology, 122(3):181.

DOI: https://doi.org/10.1007/s00418-004-0700-2 


\section{Jürgen Roth • Detlev Drenckhahn \\ A note to our authors}

Published online: 27 August 2004

(C) Springer-Verlag 2004

We would like to thank you for your support of Histochemistry and Cell Biology and to inform you about recent significant and exciting developments.

The 2003 impact factor of Histochemistry and Cell Biology is 2.581, which places it as the first-ranked journal in the categories of Histochemistry and of Microscopy. The impact factor is but one indication of the relevance and importance of the work appearing in the journal. The findings published in Histochemistry and Cell Biology are of high immediate interest reflected in the immediacy index which is as high as 1.151.

Since 2001, no charges at all are made for publication of color illustrations, and no manuscript processing fees, page charges, or charges for halftone illustrations are levied. Authors who submit their work to Histochemistry and Cell Biology can expect quick and fair review. The option for online submission of manuscripts will be available by October 2004. This will further reduce the turnaround time of the manuscripts and speed up their publication by Online First and in the print edition. Currently, accepted manuscripts are published by Online First within three to four weeks and in print after an additional one to two months, which are considered to be the fastest times of publication among the journals in the field.

The newly introduced Springer Open Choice offers all Springer journal authors the opportunity to make their newly submitted and accepted articles publicly available to anyone in the world with access to the internet. If an author chooses to publish his or her article in a Springer journal utilizing Springer Open Choice, the article will receive the same benefits of publication as any other article published by Springer. To find out more please visit http://www.springeronline.com/openchoice.

The editors of Histochemistry and Cell Biology and Springer thank you for your continued support and manuscript submissions.

\footnotetext{
J. Roth $(\bullet)$

Division of Cell and Molecular Pathology,

Department of Pathology,

University of Zürich,

Schmelzbergstrasse 12, CH-8091 Zurich, Switzerland

e-mail: juergen.roth@usz.ch

Tel.: +41-44-2555091

Fax: +41-44-2554407

D. Drenckhahn

Institute of Anatomy and Cell Biology,

Julius Maximilian University,

Koellikerstrasse 6, D-97070 Würzburg, Germany
} 